\title{
Assessing genotoxic potential of petroleum refinery wastewater using biomarkers of laboratory exposed and field captured fishes
}

\author{
Nadeeka R. Weerakkodige ${ }^{1}$, Chamini K. Hemachandra ${ }^{2}$ and Asoka Pathiratne ${ }^{1 *}$ \\ ${ }^{1}$ Department of Zoology and Environmental Management, Faculty of Science, University of \\ Kelaniya, Kelaniya, Sri Lanka \\ ${ }^{2}$ Department of Environmental Technology, Faculty of Technology, University of Colombo, \\ Pitipana, Homagama, Sri Lanka \\ *Corresponding author (asoka@kln.ac.lk)
}

ORCID: https://orcid.org/0000-0002-2961-9064

Received: 05.05.2021 Revised: 13.06.2021 Accepted: 17.06.2021 Online:15.09.2021

\begin{abstract}
Petroleum refinery wastes contain mixtures of toxic compounds including Polycyclic Aromatic Hydrocarbons (PAH) which may pose genotoxic threats to the biota. The objective of the present study was to assess the genotoxic potential of wastewaters of the petroleum refinery at Sapugaskanda, Sri Lanka using erythrocytic micronuclei and nuclear abnormalities as genotoxic biomarkers in the fish Oreochromis niloticus exposed to the refinery wastewater under controlled laboratory conditions and in the field captured fishes from the canals close to the refinery. Erythrocytic micronuclei and nuclear abnormalities in the peripheral blood were evaluated using cytogenetic tests. Patterns of fluorescent aromatic compounds in the fish bile were also examined using fixed fluorescence spectrometry to assess potential PAH exposure. Erythrocytic micronuclei, nuclear buds and notched nuclei in the peripheral blood were highly induced $(\mathrm{P}<0.05)$ in O. niloticus exposed to the wastewater for 7 days under laboratory conditions in comparison to the control fish. The field-captured fishes, Trichogaster pectoralis and Dawkinsia singhala inhabiting water canals near the petroleum refinery also demonstrated significant induction $(\mathrm{P}<0.05)$ of erythrocytic micronuclei and other nuclear abnormalities. PAH exposure indicative bile fluorescence patterns (naphthalene, phenanthrene, pyrene, and benzo(a)pyrene types) were detected in the fish exposed to the wastewater under laboratory conditions and in the field captured fishes. The results revealed that the wastewater of petroleum refinery contains genotoxic chemicals including PAHs. Hence, incorporation of genotoxicity tests as bioanalytical tools for regulating the discharge of final refinery wastewater to the aquatic ecosystems would be prudent in consideration of sustainable development goals focusing on the ecosystem and human safety.
\end{abstract}

Keywords: Bile fluorescent aromatic compounds; genotoxicity; petroleum refinery wastewater; polycyclic aromatic hydrocarbons; fish micronuclei; nuclear abnormality

\section{INTRODUCTION}

The petroleum industry generates large volumes of wastewater as petroleum refining is a waterintensive practice. Petroleum refinery waste may contain a great variety of organic and inorganic contaminants such as hydrocarbons, phenols, heavy metals, sulfides, ammonia, nitrogen compounds, oil, and grease as well as suspended solids (Daflon et al. 2017; Varjani et al. 2017; Saien and Shahrezaei 2012). Although most of these compounds/ substances are treated and recovered in the refinery before they enter the final effluent, a significant amount of toxic contaminants can enter the wastewater. Hence concern on the toxicity of final wastewater generated by the petroleum refining industry has been increased in recent years due to the potential health threats associated with their release into the waterways (Almasi et al. 2014; Daflon et al. 2017).

Bioassays and biomarkers are considered modern bio-analytic tools for assessing environmental quality (Wieczerzak et al. 2016). In recent years, genotoxic and mutagenic potential of petroleum refinery effluents has been assessed using various bioassays (Gupta et al. 2015; Hara 
and Marine-Morales 2017; Iqbal et al. 2017). Induction of micronuclei and other nuclear abnormalities in the cells are considered as biomarkers of the genotoxic damage (Heddle et al. 1991; Van der Oost et al. 2003; Arslan et al. 2015; Hemachandra and Pathiratne 2016; Hemachandra and Pathiratne 2017). Fish are excellent animal models for assessing the potential genotoxicity of refinery effluents discharged to aquatic ecosystems. Previous studies have reported induction of micronuclei in the fish Oreochromis niloticus upon exposure to the effluents from several petroleum refineries (Cavas and Ergene-Gozukara 2005; Hoshina et al. 2008; Hoshina \& Marin-Morales 2010) and river water affected by a refinery effluent (Souza and Fontanetti 2006, Hara et al. 2017; Radelyuk et al. 2021).

Polycyclic Aromatic Hydrocarbons (PAHs) are considered the most likely cause for genotoxicity associated with petroleum refinery effluents (Rodrigues et al. 2010; Vargini et al. 2017). PAH parent molecules and highly reactive intermediates produced during biotransformation of PAH within the body may induce deleterious effects on the genetic material leading to mutations and cancers (Shafy and Mansour 2016). As bile represents the major excretory route for the biotransformed PAH metabolites in the fish, biliary fluorescence patterns relevant to specific PAH metabolites can be used as biomarkers for assessing the exposure of fish populations to PAHs (Van der Oost et al. 2003; Johnson-Restrepo 2008; Beyer et al. 2010, Bali et al. 2016). PAH contamination in some inland water bodies in Sri Lanka had been assessed based on bile fluorescence patterns as biomarkers of exposure in resident fish species (Pathiratne et al. 2010; Hemachandra and Pathiratne 2011; Ranasinghe and Pathiratne 2015).

The petroleum refinery located at Sapugaskanda in Gampaha District is the single largest oil refinery of Sri Lanka. It plays a major role in the Sri Lankan economy and petroleum has been identified as a nonindigenous energy form that can supplement the local resources in fulfilling the energy demand of the country. Physico-chemical characteristics of wastewater discharged from the petroleum refinery are expected to comply with the tolerance limits of the general standards of industrial effluents discharged into inland surface waters in Sri Lanka (Anonymous 2008). However, no scientific studies had been conducted to assess the potential toxicity of wastewater generated from this petroleum refinery and the effects associated with petrochemical pollution on surrounding ecosystems. For the first time, the present study was aimed at assessing potential genotoxicity associated with wastewater of petroleum refinery in Sri Lanka using biomarkers of laboratory exposed and field captured fishes. The genotoxic potential was assessed using erythrocytic micronuclei and nuclear abnormalities of the test fish, Oreochromis niloticus under laboratory bioassays and field captured fishes, Trichogaster pectoralis and Dawkinsia singhala inhabiting water canals near the petroleum refinery. In addition, bile fluorescence patterns in these fishes were also examined as biomarkers for potential PAH exposure.

\section{MATERIALS AND METHODS}

\section{Test fish for bioassay}

Fingerlings of Nile Tilapia, O. niloticus were obtained from the Udawalawe freshwater fish breeding station of the National Aquaculture Development Authority of Sri Lanka. Fish were kept in large circular tanks filled with aerated aged tap water for two weeks for acclimation to laboratory conditions. Half of the water in the tanks was renewed every 2 days. The fish were daily fed with commercial fish food pellets. Fish were not fed 24 hours before the commencement of the bioassay. During the acclimation period, temperature, $\mathrm{pH}$ and dissolved oxygen (DO) concentration in the water tanks (range: minimum to maximum) were 26$30^{\circ} \mathrm{C}, 6.8-7.1$, and $4-5 \mathrm{mg} / \mathrm{L}$ respectively.

\section{Petroleum refinery wastewater}

In the present study, samples of petroleum refinery final wastewater were collected into double-walled polythene bags from wastewater pond of Petroleum refinery Division of Ceylon Petroleum Corporation $\left(6^{\circ} 58^{\prime} 45^{\prime \prime N}\right.$; 79 $\left.75^{\circ} 40^{\prime \prime E}\right)$ in June 2011 and transported within 30 minutes to the laboratory for the bioassay. Temperature, $\mathrm{pH}$, Total Dissolved Solids (TDS) and DO levels in the composite wastewater samples were measured in situ using calibrated multiprobe water quality checker (YSI/Model: 556 MPS, USA). For the determination of selected chemical parameters, wastewater samples were brought to the laboratory 


\section{N.R. Weerakkodige et al.}

in glass bottles. Biochemical Oxygen Demand (BOD5), Chemical Oxygen Demand (COD), oil and grease levels in the wastewater were measured following APHA (1998).

\section{Fish bioassay: Laboratory exposure to refinery} wastewater

O. niloticus ( $8.9 \pm 0.2 \mathrm{~cm}$ in total length, $10.3 \pm 0.8 \mathrm{~g}$ in body weight) which had been acclimated to the laboratory conditions were exposed separately to $50 \%$ and $100 \%$ of petroleum refinery wastewater samples in glass tanks $(40 \mathrm{~L})$ in triplicates $(n=10$ fish per tank) for 7 days under static conditions. Concurrently the fishes in another three sets of tanks ( $n=10$ fish per tank) were maintained in the aged tap water used for dilution of the wastewater samples (dilution water control). The exposure media were moderately aerated. General water quality parameters in the fish tanks with the dilution water and $50 \%$ and $100 \%$ of the wastewater used for exposure studies were measured daily using the water quality checker (YSI/Model: 556 MPS, USA) and found to be within the desirable limits for fish (temperature: $27-28^{\circ} \mathrm{C}$, pH:7-7.4, and DO levels: 4.9-5.3 $\mathrm{mg} / \mathrm{L})$. The Oil and grease content of the exposure media was measured on day one of the bioassays as described by APHA (1998). Oil and grease content in the $50 \%$ and $100 \%$ of wastewater were 3.4 and $7.2 \mathrm{mg} / \mathrm{L}$ respectively. Oil and grease were not detected in the dilution water. Fish were not fed during the seven days exposure period. After 2 days of exposure, ten fish representing each exposed water type were sampled randomly from each replicate tank (3-4 fish per tank) for biomarker studies. The remaining fish were maintained under static exposure conditions and sampled again on the 7th day for biomarker studies. The remaining fish were sacrificed individually under an overdose of the anaesthesia (70 $\mathrm{mg} / \mathrm{L}$ Benzocaine). Blood was drawn from the caudal vein of each fish onto a glass slide and a thin smear of blood was prepared, airdried, and processed further as described below for assessment of erythrocytic micronuclei and nuclear abnormalities. Bile samples were taken from each fish to Eppendorf tubes and frozen at $-80^{\circ} \mathrm{C}$ until bile fluorescence analysis. All applicable international guidelines for the care and use of animals were followed in this study concerning the laboratory maintenance and bioassessment with the fish.

\section{Field captured fish in the canals near Petroleum Refinery}

The Pattiwila canal and Heiyanthuduwa canal flows through the area under the influence of the Petroleum Refinery at Sapugaskanda (Figure 1). In the present study, three sites of the Pattiwila canal (Sites A, B and C) and one site of the Heiyanthuduwa canal (Site D) were selected for capturing wild fish species for biomarker assessments. Site A which is situated behind the Petroleum Refinery, Sapugaskanda, is the source point (6 ${ }^{\circ} 57^{\prime} 24.37^{\prime \prime N}$; 7957'28.66") from which the Pattiwila canal commences. Site B (6 $6^{\circ} 7^{\prime} 06.24 " N$; $\left.79^{\circ} 57^{\prime} 03.58^{\prime \prime} \mathrm{E}\right)$ is the middle stream of the Pattiwila canal which is situated about $1.2 \mathrm{~km}$ away from the site A. Site C (6 $\left.56^{\prime} 17.91 " N ; 79^{\circ} 57^{\prime} 31.51^{\prime \prime E}\right)$ is downstream of the Pattiwila canal which is about $0.8 \mathrm{~km}$ away from site B. Site D $\left(6^{\circ} 58^{\prime} 08.52^{\prime \prime N}\right.$; $\left.79^{\circ} 57^{\prime} 28.30^{\prime \prime} \mathrm{E}\right)$ is located in the Heiyanthuduwa canal which is located in the vicinity of the petroleum refinery. In addition, a relatively less polluted water body, Bathalagoda reservoir $\left(7^{\circ} 45^{\prime} \mathrm{N}\right.$; $\left.80^{\circ} 37^{\prime} \mathrm{E}\right)$ was used as the reference site (Site R) as no other suitable reference site could be found in the canals near the area. Temperature, $\mathrm{pH}$, TDS, and DO levels of surface water of each site were measured onsite in July 2011 using the water quality checker. BOD5, COD, and oil and grease contents in the surface water samples were determined as described by APHA (1998). Snakeskin gourami, Trichogaster pectoralis ( $7.7 \pm 0.3 \mathrm{~cm}$ in total length, $6.8 \pm 0.4 \mathrm{~g}$ body weight) were collected from the three sites in Pattiwila canal whereas blackspot barb, Dawkinsia singhala (6.8 $\pm 0.3 \mathrm{~cm}$ in total length, $6.1 \pm 0.2 \mathrm{~g}$ body weight) were collected from Heiyanthuduwa canal using cast nets. They were commonly available fish species in these study sites. In addition, samples of T. pecoralis $(7.9 \pm 0.3 \mathrm{~cm}$ in total length, $6.9 \pm 0.3 \mathrm{~g}$ body weight) and $D$. singhala $(6.4 \pm 0.2 \mathrm{~cm}$ in total length, $5.9 \pm 0.3 \mathrm{~g}$ body weight) were collected from the reference site (Bathalagoda reservoir) using cast nets for comparison. These fish were collected into polythene bags filled with water samples collected from the same habitat and the water in the bags was well oxygenated. The fish samples were transported to the laboratory and peripheral blood samples and bile samples were taken from each fish for biomarker studies as mentioned previously. 


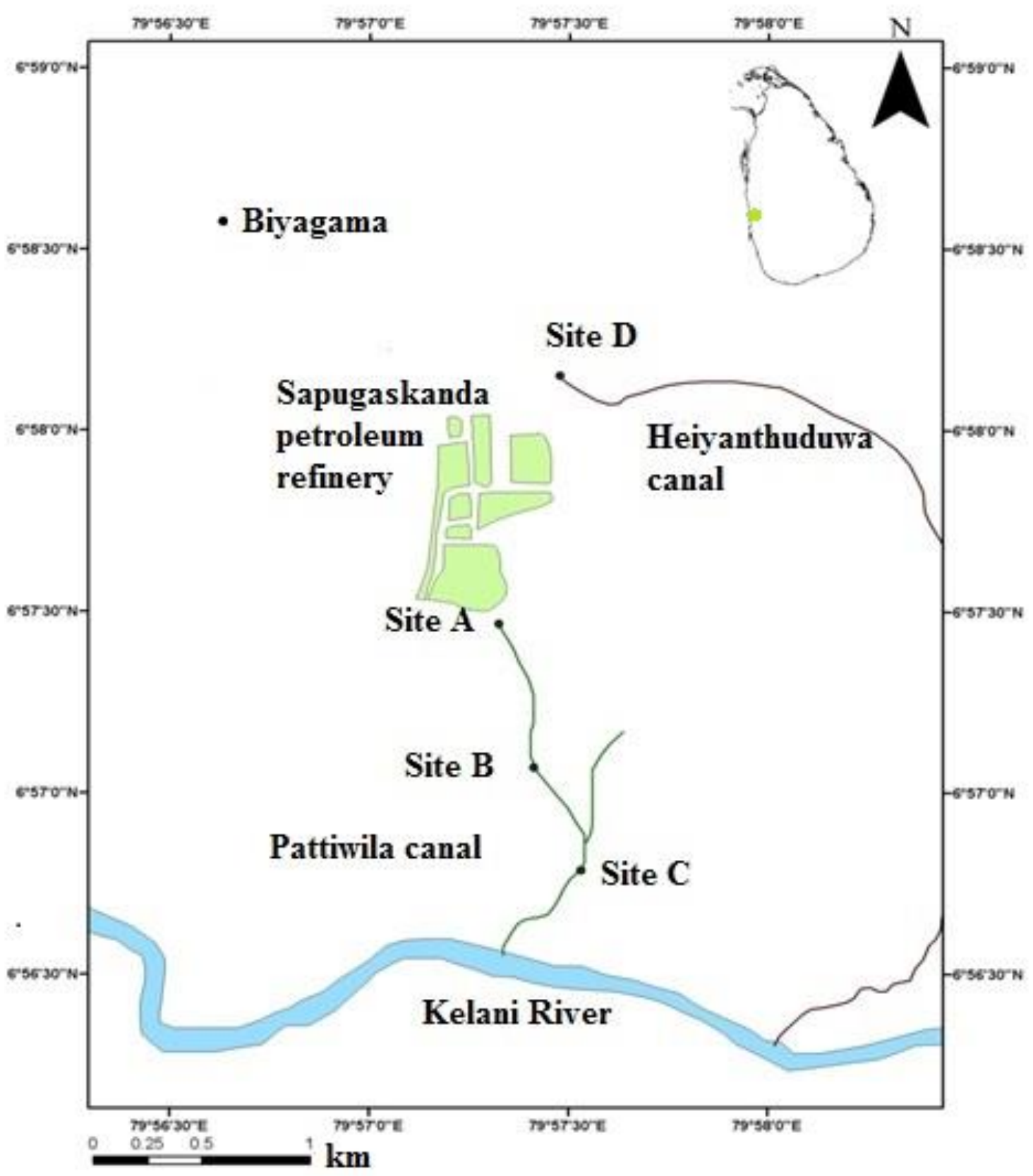

Fig 1 Location of the fish captured from the canals near petroleum refinery at Sapugaskanda for biomarker studies: Site A: upstream of the Pattiwila canal, Site B: middle stream of the Pattiwila canal, Site C: downstream of the Pattiwila Canal, Site D: the Heiyanthuduwa canal

\section{Genotoxicity assessment}

Peripheral blood samples were smeared onto glass microscope slides and were air-dried. The slides were fixed in methanol for 20 minutes and stained for 7 minutes with 5\% Giemsa solution (Cavas and
Ergene-Gozukara 2005). The slides were rinsed with distilled water, air-dried, and examined under oil immersion ( $\times 1000$ magnification) of a binocular bright light microscope. At least 1000 erythrocytes were examined for each fish on coded slides. Small, non-refractive, circular, or ovoid chromatin bodies 
N.R. Weerakkodige et al.

in the cytoplasm, displaying the same staining and focusing pattern as the main nucleus, were scored as micronuclei (Al-Sabti and Metcalfe 1995). Nuclear abnormalities in the erythrocytes other than micronuclei were classified as nuclear buds, binuclei, and notched nuclei (Cavas and ErgeneGozukara 2005). Nuclear buds were characterized as extruded nuclear material that appears like a micronucleus with a narrow bridge to the main nucleus. The erythrocytes with two nuclei were considered binucleated cells. Nuclei with voids with appreciable depth into the nucleus were recorded as notched nuclei. The frequencies of micronuclei, nuclear buds, bi-nuclei, and notched nuclei in the erythrocytes were expressed separately as numbers per 1000 erythrocytes examined (\%o).

\section{Detection of fluorescent aromatic compounds in fish bile}

PAH metabolites in fish bile were screened by detecting fluorescent aromatic compounds with fixed wavelength fluorescence technique using computer-controlled Varian Cary Eclipse fluorescence spectrophotometer. Two $\mu \mathrm{L}$ of bile diluted in $4 \mathrm{~mL}$ of $48 \%$ ethanol were used to decrease the absorption and quenching of the fluorescence signal. Fluorescence measurements were performed in quartz cuvettes. Fixed wavelength fluorescence at the excitation/emission wavelength pairs $290 / 335 \mathrm{~nm}$ and $341 / 383 \mathrm{~nm}$ and $380 / 430 \mathrm{~nm}$ were used for detection of naphthalene type, pyrene type, and benzo(a)pyrene type metabolites respectively as described by Aas et al. (2000). Fixed wavelength fluorescence at the wavelength pair 260/380 nm was used for the detection of phenanthrene type-metabolites (Krahn et al. 1993). The slit width was set at $2.5 \mathrm{~nm}$ for the detection of PAH metabolites. The fixed fluorescence at the respective wavelength pair was expressed as arbitrary fluorescence units (A.F.U.).

\section{Statistical analysis}

Micronuclei and nuclear abnormality data were subjected to ArcSin transformation and other data were transformed to $\log _{10}(\mathrm{x}+1)$ scale where appropriate before statistical analysis (Zar 1998). The transformed data on frequencies of micronuclei and other nuclear abnormalities, and bile fluorescence measurements of the fishes, $O$. niloticus and $T$. pectoralis, were analyzed separately using one-way analysis of variance test. If there were significant differences, Tukey's test was used for the comparison of means. The accepted level of significance was $\mathrm{P}<0.05$. Student's t-test was used for comparison of the data sets on the fish, D. singhala.

\section{RESULTS}

\section{Physico-chemical characteristics of refinery wastewater and surface water of canals near the refinery}

Measured physico-chemical parameters of the composite sample of petroleum refinery wastewater were within the acceptable limits for discharge of industrial effluents into inland surface waters in Sri Lanka (Table 1). Physico-chemical parameters of the water in the Pattiwila and Heiyanthuduwa canals near petroleum refinery and the reference site (Bathalagoda reservoir) indicate that the TDS, BOD5, COD, and oil and grease levels in the Site A of Pattiwila canal and Site D of Heiyanthuduwa canal were comparatively higher than those of the other sites (Table 1).

\section{Genotoxicity assessment of $O$. niloticus exposed to the refinery wastewater under laboratory conditions}

All $O$. niloticus could survive until the end of the exposure period. However, the fish exposed to $50 \%$ and $100 \%$ of the wastewater were lethargic and displayed sluggish behavior at 5 days of exposure onwards compared to the control fish. Erythrocytes with micronucleus and different types of nuclear abnormalities (nuclear bud, binuclei, and notched nucleus) seen in the examined blood smears of $O$. niloticus are shown in Figures 2(a) to 2(d). The fish exposed to $100 \%$ wastewater showed significant induction of micronuclei after 2 days and 7 days exposure (Table 2). Concentration-dependent significant increase in the occurrence of erythrocytes with nuclear buds or notched nuclei were seen in the fish exposed to the refinery wastewater at 2 days and 7 days of exposure. Binuclei were not seen in the control fish, but a significant increase in the occurrence of binucleated erythrocytes was observed in the fish exposed to $100 \%$ wastewater (Table 2). 
Table 1 Measured physico-chemical parameters of the petroleum refinery wastewater and the surface water in the canals near Petroleum Refinery and reference site

\begin{tabular}{|c|c|c|c|c|c|c|c|}
\hline \multirow{2}{*}{ Parameter } & \multirow{2}{*}{$\begin{array}{l}\text { National } \\
\text { tolerance limits* }\end{array}$} & \multirow{2}{*}{$\begin{array}{c}\text { Refinery } \\
\text { wastewater }\end{array}$} & \multicolumn{3}{|c|}{ Pattiwila Canal } & \multirow{2}{*}{$\begin{array}{c}\begin{array}{c}\text { Heiyanthuduwa } \\
\text { Canal }\end{array} \\
\text { Site D }\end{array}$} & \multirow{2}{*}{$\begin{array}{c}\text { Reference site } \\
\text { (Bathalagoda } \\
\text { reservoir) }\end{array}$} \\
\hline & & & Site A & Site B & Site C & & \\
\hline Temperature $\left({ }^{\circ} \mathrm{C}\right)$ & $<40$ & 31 & 30 & 30 & 31 & 32 & 30 \\
\hline $\mathrm{pH}$ & $6-8.5$ & 7.47 & 7.4 & 7.4 & 7.3 & 7.3 & 7.1 \\
\hline $\begin{array}{l}\text { Total dissolved solids } \\
(\mathrm{mg} / \mathrm{L})\end{array}$ & - & 100 & 108 & 88 & 49 & 308 & 26 \\
\hline $\begin{array}{l}\text { Dissolved Oxygen } \\
(\mathrm{mg} / \mathrm{L})\end{array}$ & - & 4.7 & 4.3 & 4.2 & 4.6 & 4.1 & 5.2 \\
\hline $\begin{array}{l}\text { Biochemical oxygen } \\
\text { demand } 5 \text { days }(\mathrm{mg} / \mathrm{L})\end{array}$ & 30 & 20 & 12 & 5 & 3 & 22 & 2 \\
\hline $\begin{array}{l}\text { Chemical oxygen } \\
\text { demand }(\mathrm{mg} / \mathrm{L})\end{array}$ & 250 & 110 & 57 & 22 & 26 & 75 & 10 \\
\hline Oil and grease $(\mathrm{mg} / \mathrm{L})$ & 10 & 7.2 & 1.6 & 0.4 & 0.1 & 1.8 & 0 \\
\hline
\end{tabular}

*Tolerance limits for discharge of industrial effluents into inland surface waters in Sri Lanka assuming at least 8 times dilution with clean receiving water (Anon. 2008) 

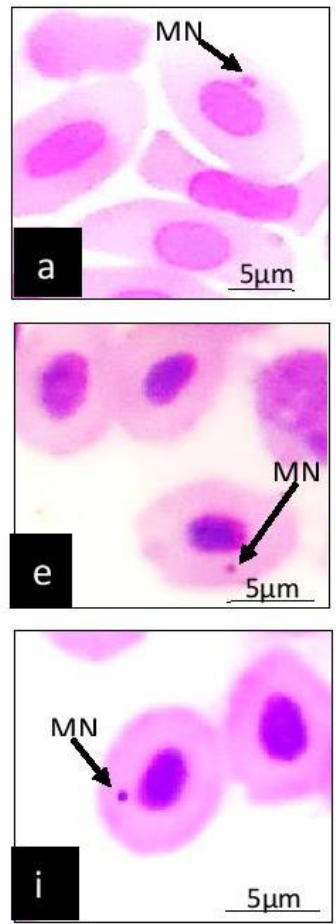
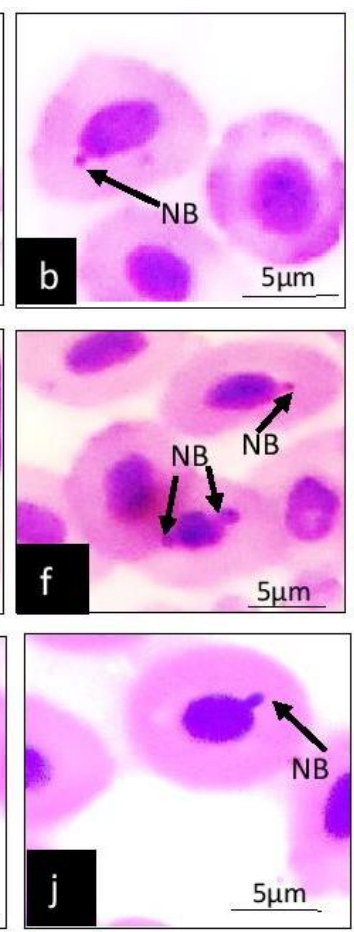
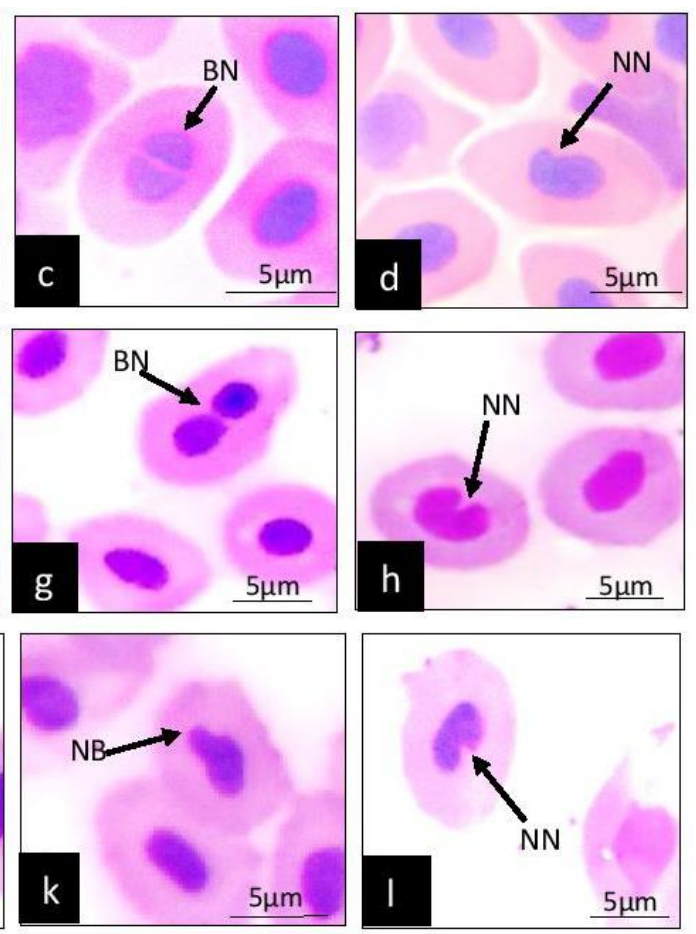

Fig 2 Erythrocytic micronuclei and nuclear abnormalities found in the blood of test fishes: O. niloticus (a, $\mathrm{b}, \mathrm{c}, \mathrm{d})$ following exposure to petroleum refinery wastewater in the laboratory; field captured T. pectoralis $(\mathrm{e}, \mathrm{f}, \mathrm{g}, \mathrm{h})$ and $D$. singhala $(\mathrm{i}, \mathrm{j}, \mathrm{k}, \mathrm{l})$ residing canals near the petroleum refinery. MN: Micronucleus; NB: Nuclear bud; BN: Binuclei; NN: Notched nucleus

Table 2 Occurrence of erythrocytic micronuclei, nuclear buds, binuclei and notched nuclei in the peripheral blood of $O$. niloticus after two days and seven days exposure in the laboratory to petroleum refinery wastewater

\begin{tabular}{|c|c|c|c|c|}
\hline \multirow{2}{*}{ Exposure } & \multicolumn{4}{|c|}{ Occurrence of nuclear abnormality (\%o) } \\
\hline & Micronuclei & Nuclear buds & Binuclei & Notched nuclei \\
\hline \multicolumn{5}{|l|}{2 days } \\
\hline $\begin{array}{r}\text { Control (dilution } \\
\text { water) }\end{array}$ & $\begin{array}{l}0.1 \pm 0.1^{\mathrm{a}} \\
\quad(0-1)\end{array}$ & $\begin{array}{l}0.5 \pm 0.3^{\mathrm{a}} \\
\quad(0-2)\end{array}$ & $0 \pm 0^{\mathrm{a}}$ & $\begin{array}{c}3.5 \pm 0.7^{\mathrm{a}} \\
(1-6)\end{array}$ \\
\hline $50 \%$ wastewater & $\begin{array}{c}1.5 \pm 0.5^{\mathrm{a}} \\
(0-4)\end{array}$ & $\begin{array}{c}6.6 \pm 1.8^{\mathrm{b}} \\
(0-21)\end{array}$ & $\begin{array}{l}0.5 \pm 0.3^{\mathrm{a}} \\
(0-2)\end{array}$ & $\begin{array}{c}19.3 \pm 4.6^{\mathrm{b}} \\
(12-25)\end{array}$ \\
\hline $100 \%$ wastewater & $\begin{array}{c}5.5 \pm 0.9^{b} \\
(1-10)\end{array}$ & $\begin{array}{c}17.7 \pm 1.6^{c} \\
(11-29)\end{array}$ & $\begin{array}{c}3.9 \pm 0.6^{\mathrm{b}} \\
(1-7)\end{array}$ & $\begin{array}{c}31.3 \pm 6.5^{\mathrm{c}} \\
(26-56)\end{array}$ \\
\hline \multicolumn{5}{|l|}{7 days } \\
\hline $\begin{array}{r}\text { Control (dilution } \\
\text { water) }\end{array}$ & $\begin{array}{l}0.1 \pm 0.1^{\mathrm{a}} \\
\quad(0-1)\end{array}$ & $\begin{array}{l}0.7 \pm 0.4^{\mathrm{a}} \\
\quad(0-3)\end{array}$ & $0 \pm 0^{\mathrm{a}}$ & $\begin{array}{c}4.3 \pm 0.6^{\mathrm{a}} \\
(1-7)\end{array}$ \\
\hline $50 \%$ wastewater & $\begin{array}{l}2.5 \pm 0.5^{\mathrm{a}} \\
(1-5)\end{array}$ & $\begin{array}{c}12.3 \pm 2.7^{b} \\
(1-24)\end{array}$ & $\begin{array}{l}1.4 \pm 0.5^{\mathrm{a}} \\
\quad(0-4)\end{array}$ & $\begin{array}{c}18.8 \pm 5.4^{\mathrm{b}} \\
(13-27)\end{array}$ \\
\hline $100 \%$ wastewater & $\begin{array}{c}9.0 \pm 1.6^{b} \\
(1-17) \\
\end{array}$ & $\begin{array}{c}31.6 \pm 2.9^{c} \\
(12-44)\end{array}$ & $\begin{array}{c}5.5 \pm 0.5^{\mathrm{b}} \\
(2-8)\end{array}$ & $\begin{array}{c}42.8 \pm 7.9^{c} \\
(32-61)\end{array}$ \\
\hline
\end{tabular}

* Data are presented as Mean \pm SEM (Minimum and maximum range), $n=10$ fish per group. In a column, for a specific exposure duration, data indicated with different superscripts are significantly different from each other. ( $\mathrm{P}<0.05)$. 
Figure 3 shows the fixed fluorescence intensities of bile of O. niloticus exposed to 50\% and $100 \%$ of petroleum refinery wastewater and the dilution water (control) after 2 days and 7 days exposure. Bile fluorescence intensities corresponding to naphthalene-type and phenanthrene-type metabolites were significantly higher in the fish exposed to the $50 \%$ and $100 \%$ wastewater in comparison to the respective controls (Figure 3). However, no significant differences were observed either with the duration of exposure or strength of the wastewater to these metabolite types. Bile fluorescence intensity corresponding to phenanthrene-type metabolites was decreased at 7 days exposure to $100 \%$ wastewater in comparison to 2 days exposure. Bile fluorescence intensity corresponding to pyrene-type metabolites was significantly higher than controls only in the bile of fish exposed to $50 \%$ wastewater for 7 days. The fluorescence intensity of benzo(a)pyrene-type metabolites was significantly higher only in the fish exposed to $50 \%$ wastewater after 2 days and 7 days of exposure in comparison to the control fish (Figure 3).

\section{(a) Naphthalene type metabolites}

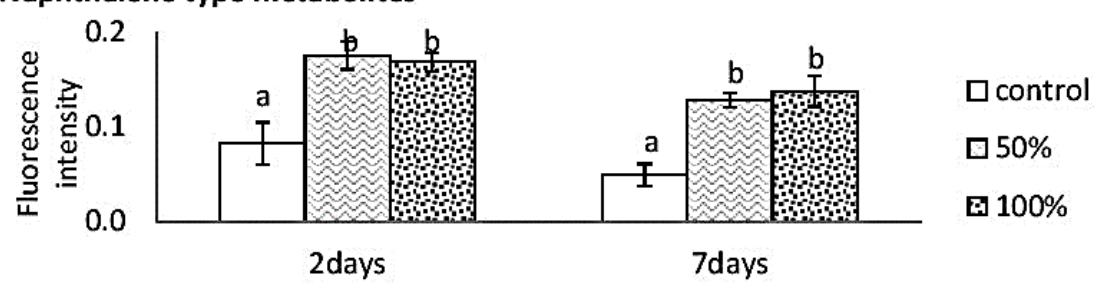

(b) Phenanthrene type metabolites

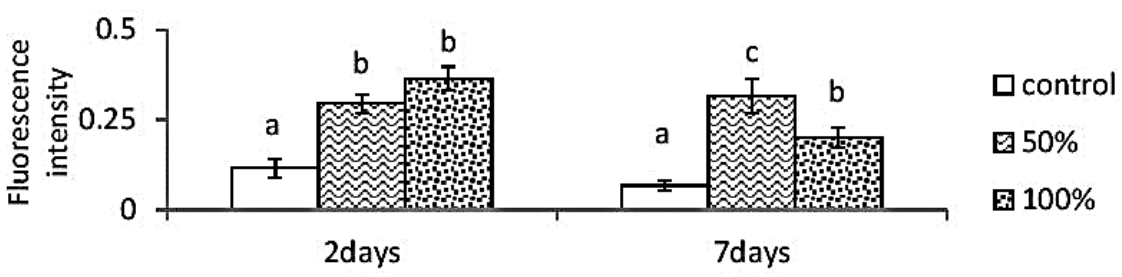

(c) Pyrene type metabolites

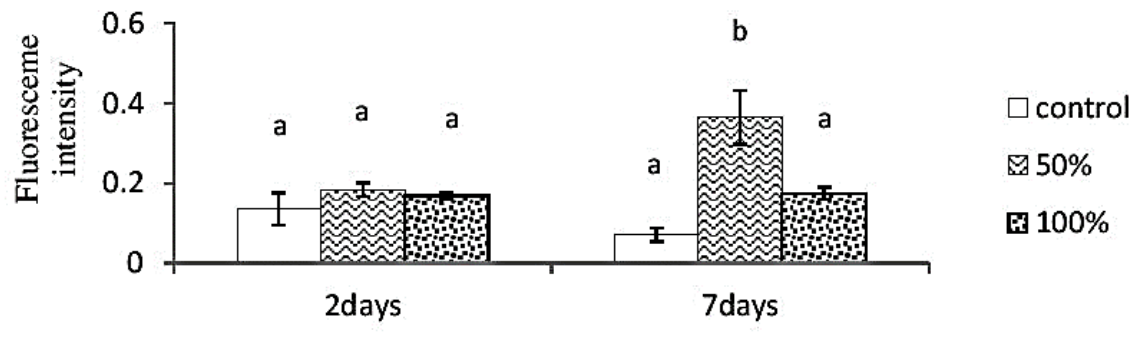

(d) Benzo(a)pyrene type metabolites

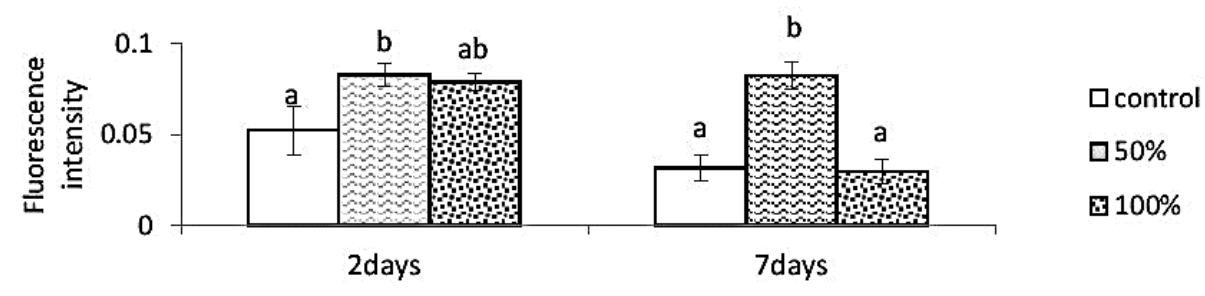

Fig 3 Fixed fluorescence intensities (arbitrary fluorescent units) of bile of $O$. niloticus exposed to $50 \%$ and $100 \%$ of petroleum refinery wastewater and the dilution water (control) after 2 days and 7 days exposure. Results are presented as mean \pm SEM, $n=10$ fish per group. For each category, bars indicated with different letters are significantly different from each other $(\mathrm{P}<0.05)$. 


\section{N.R. Weerakkodige et al.}

Genotoxicity assessment of $T$. pectoralis and $D$. singhala collected from canals near the petroleum refinery

Erythrocytes with micronuclei and nuclear buds, binuclei, and notched nuclei seen in the examined blood smears of field captured $T$. pectoralis are presented in Figure 2 (e) to 2 (h). Binuclei were seen only in the erythrocytes collected from $T$. pectoralis collected from Site A. Significantly higher occurrence of micronuclei, and nuclear buds were observed in the erythrocytes of $T$. pectoralis (Table 3) collected from site A of Pattiwila canal in comparison to the fish from the control site and other sites (B and C). The frequency of erythrocytes with notched nuclei was significantly higher in the blood of T. pectoralis captured from sites A and B in comparison to those from the reference site and site C. In the blood smears of D. singhala only erythrocytes with micronuclei, nuclear buds, and notched nuclei were seen (Figure 2 (i) to 2 (1)) in addition to the normal erythrocytes. Micronuclei were not seen in $D$. singhala captured from the reference site whereas induction of micronuclei up to $21 \%$ was observed in some individuals of $D$. singhala captured from Site $\mathrm{D}$ of the Heiyanthuduwa canal. Erythrocytes with nuclear buds and notched nuclei were significantly higher in D. singhala captured from the Heiyanthuduwa canal in comparison to those from the reference site (Table 3).

Table 3 Occurrence of erythrocytic micronuclei, nuclear buds, binuclei and notched nuclei in the peripheral blood of field captured $T$. pectoralis and D. singhala inhabiting the canals near petroleum refinery (Sites A, B, C of the Pattiwila canal and Site D of Heiyanthuduwa canal)

\begin{tabular}{|c|c|c|c|c|}
\hline \multirow{2}{*}{ Fish and sampling site } & \multicolumn{4}{|c|}{ Occurrence of nuclear abnormality (\%o) } \\
\hline & Micronuclei & Nuclear buds & Binuclei & Notched nuclei \\
\hline \multicolumn{5}{|l|}{ T. pectoralis } \\
\hline Site A & $\begin{array}{c}17.8 \pm 1.7^{b} \\
(14-22)\end{array}$ & $\begin{array}{c}14.8 \pm 2.2^{b} \\
(10-23)\end{array}$ & $0.4 \pm 0.4^{\mathrm{a}}$ & $\begin{array}{c}45.2 \pm 5.5^{\mathrm{b}} \\
(32-60)\end{array}$ \\
\hline Site B & $\begin{array}{c}0.8 \pm 0.5^{\mathrm{a}} \\
(0-2)\end{array}$ & $\begin{array}{c}5.2 \pm 0.7^{\mathrm{a}} \\
(3-7)\end{array}$ & $0 \pm 0^{\mathrm{a}}$ & $\begin{array}{c}32.4 \pm 3.6^{\mathrm{b}} \\
(22-44)\end{array}$ \\
\hline Site $\mathrm{C}$ & $\begin{array}{c}0.4 \pm 0.4^{\mathrm{a}} \\
(0-2)\end{array}$ & $\begin{array}{c}1.2 \pm 0.8^{\mathrm{a}} \\
(0-4)\end{array}$ & $0 \pm 0^{\mathrm{a}}$ & $\begin{array}{c}15.4 \pm 2.1^{\mathrm{a}} \\
(11-23)\end{array}$ \\
\hline Reference site & $\begin{array}{c}0.2 \pm 0.2^{\mathrm{a}} \\
(0-1)\end{array}$ & $\begin{array}{c}1.0 \pm 0.4^{\mathrm{a}} \\
(0-3)\end{array}$ & $0 \pm 0^{\mathrm{a}}$ & $\begin{array}{c}11.8 \pm 1.1^{\mathrm{a}} \\
(9-15)\end{array}$ \\
\hline \multicolumn{5}{|l|}{ D. singhala } \\
\hline Site D & $\begin{array}{c}14.4 \pm 2.4^{\mathrm{b}} \\
(7-21)\end{array}$ & $\begin{array}{c}17.0 \pm 1.9^{\mathrm{b}} \\
(12-22)\end{array}$ & $0 \pm 0^{\mathrm{a}}$ & $\begin{array}{c}42.2 \pm 5.4^{\mathrm{b}} \\
(23-53)\end{array}$ \\
\hline Reference site & $0 \pm 0^{\mathrm{a}}$ & $\begin{array}{c}1.8 \pm 0.7^{\mathrm{a}} \\
(0-3)\end{array}$ & $0 \pm 0^{\mathrm{a}}$ & $\begin{array}{c}10.2 \pm 1.3^{\mathrm{a}} \\
(7-14)\end{array}$ \\
\hline
\end{tabular}

*Data are presented as Mean \pm SEM (Minimum and maximum range), $\mathrm{n}=5$ fish per group. In a column, for a particular species, data indicated with different superscripts are significantly different from each other. $(\mathrm{P}<0.05)$. Reference site (Site R) is the Bathalagoda reservoir

Bile fluorescence (fixed fluorescence) intensities of field captured $T$. pectoralis and $D$. singhala are presented in Figure 4. T. pectoralis collected from site A of Pattiwila canal demonstrated significantly high fluorescent intensities corresponding to Naphthalene-type, metabolites compared to the fish from other sites of the canal and the reference site (Figure 4a). Fluorescent intensities relevant to phenanthrenetype and benzo(a)pyrene-type metabolites were significantly higher in the fish collected from Sites
A and B of the canal compared to the fish from the other sites. Pyrene-type metabolites in the bile were significantly higher in $T$. pectoralis collected from the three sites of the Pattiwila canal compared to the fish from the reference site. D. singhala captured from the Heiyanthuduwa canal (Figure 4b) demonstrated significantly higher fluorescence intensities corresponding to Naphthalene-type, Phenanthrene-type, Pyrene-type, and Benzo(a)pyrene-type metabolites in comparison to the fish collected from the site R (reference site). 
(a) Trichogaster pectoralis

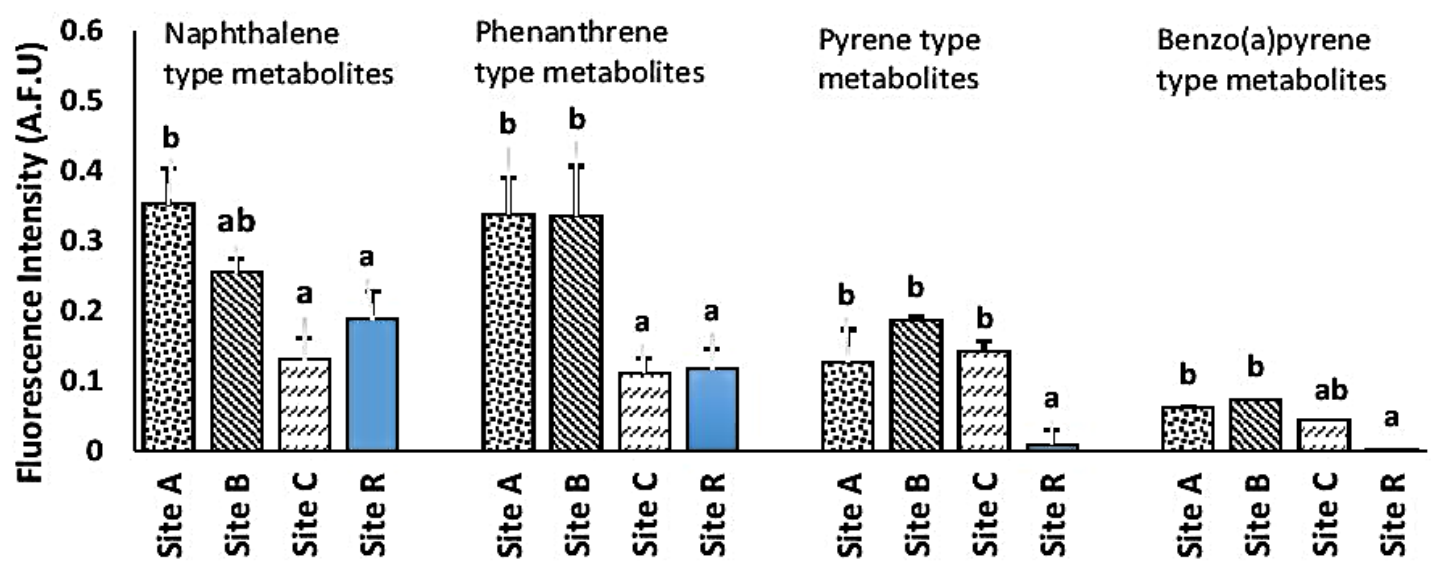

(b) Dawkinsia singhala

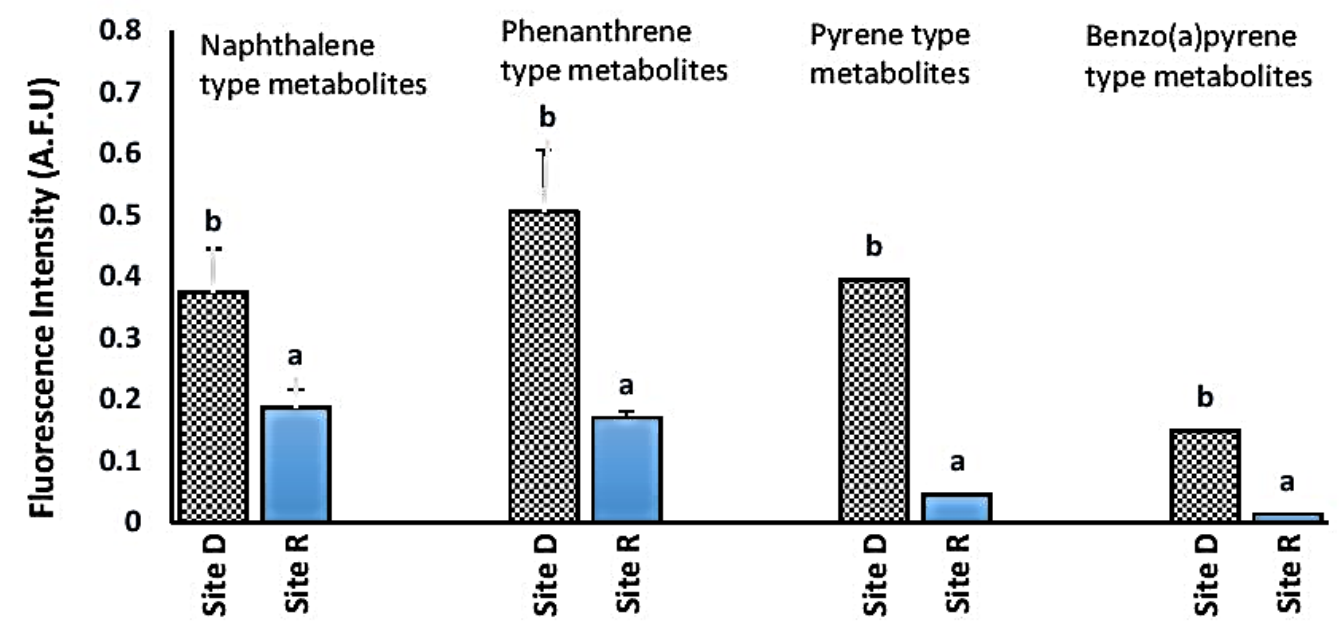

Figure 4 Fixed fluorescence intensities (arbitrary fluorescent units) of bile of $T$. pectoralis and $D$. singhala captured from canals near the petroleum refinery (Sites A, B, C of the Pattiwila canal and Site D of the Heiyanthuduwa canal) and Bathalagoda reservoir, the reference site (Site R). Results are presented as mean \pm SEM, $\mathrm{n}=5$ fish per group. For each type of metabolite, bars indicated with different letters are significantly different from each other $(\mathrm{P}<0.05)$.

\section{DISCUSSION}

The impact of wastewater generated by the petroleum refining industry on aquatic ecosystems have been increasingly concerned in recent years as the refinery waste contains genotoxic PAHs, phenols, and heavy metals which can directly or indirectly induce DNA damage (Almasi et al. 2014;
Gupta et al. 2015; Daflon et al. 2017). Testing wastewaters of several petroleum refineries by a variety of bioassays revealed that the refinery wastewaters are genotoxic and mutagenic which would pose health risks to the exposed biota (Cavas and Ergene-Gozukara 2005; Hoshina et al. 2008; Gupta et al. 2015; Iqbal et al. 2017). Genotoxic effects associated with wastewater can be assessed using fish biomarkers as early warning signals. For 


\section{N.R. Weerakkodige et al.}

the first time, the present study provided scientific evidence for genotoxic potential associated with the petroleum refinery wastewater generated by the oil refinery of Sri Lanka. Even though measured physico-chemical parameters of the tested petroleum refinery wastewater at Sapugaskanda were within the acceptable limits for discharge of industrial effluents into inland surface waters in Sri Lanka (Anonymous 2008), the wastewater exhibited genotoxic properties as revealed by induction of erythrocytic micronuclei and nuclear abnormalities in the fish $O$. niloticus exposed to the wastewater under laboratory conditions.

Among the genotoxic tests that can be conducted routinely for the genotoxic evaluation, the micronucleus test with fish is a simple, reliable, and economical test that can be used in refinery wastewater quality assessments (Al-Sabti and Metcalfe 1995; Cavas and Ergene-Gozukara 2005; Hoshina et al. 2008). Micronuclei are cytoplasmic chromatin masses with the appearance of small nuclei that arise from chromosome fragments after clastogenic action or intact whole chromosomes lagging in the anaphase stage of cell division as a result of aneugenic effects. Their presence in cells is a reflection of structural and/or numerical chromosomal aberrations arising during mitosis (Heddle et al. 1991; Udroiu 2006). In the present study, $O$. niloticus exposed to the wastewater showed significant induction $(\mathrm{P}<0.05)$ of micronuclei after 2 days and 7 days exposure indicating genotoxicity. In the field captured fishes, significantly higher frequencies of erythrocytic micronuclei were observed in $T$. pectoralis and $D$. singhala captured from the sites close to the petroleum refinery (site A of Pattiwila canal and Site D of Heiyanthuduwa canal respectively) in comparison to those from the other sites indicating the genotoxic impact associated with the refinery. Physico-chemical analysis of the surface waters of these sites revealed high TDS, COD, oil, and grease levels compared to the other sites indicating that Sites A and D of the nearby canals are more polluted than the other sites. Field studies have shown that oil refinery effluents often have an impact on the fauna, which is usually restricted to the area close to the outfall (Wake 2005). Our study with fieldcaptured fishes also showed that sites subject to petrochemical influence were under higher genotoxic impact. Micronuclei induction in fish indicates genotoxic and mutagenic effects (Heddle et al. 1991) which may eventually lead to malignancy (Hintzsche et al. 2017).

In addition to micronuclei, nuclear abnormalities have been detected in fish erythrocytes exposed to various industrial effluents indicating genotoxic impacts (Hemachandra and Pathiratne 2016; 2017; Weldetinsae et al. 2017). Although the processes such as problems in segregating tangled and attached chromosomes, aneuploidy, and cellular degradation are speculated, the mechanisms underlying the formation of such nuclear abnormalities are not fully explained (Weldetinsae et al. 2017). Concentration-dependent increase $(\mathrm{P}<0.05)$ in the frequencies of erythrocytic nuclear buds and notched nuclei were seen in $O$. niloticus exposed to the refinery wastewater at 2 days and 7 days. In the field captured fishes, significantly higher occurrence of nuclear buds and notched nuclei were observed in the erythrocytes of $T$. pectoralis and $D$. singhala captured from the sites close to the refinery in comparison to those from the other sites. Even though binuclei were not seen in $O$. niloticus exposed to the dilution water (controls), a significant increase in the frequency of binucleated erythrocytes was observed in the fish exposed to $100 \%$ wastewater. Binuclei were seen only in the erythrocytes of $T$. pectoralis captured from the Site close to the refinery (Site A). The occurrence of binucleated cells is an indicator of abnormal cell division due to the blocking of cytokinesis which would result in a genetic imbalance in the cells (Weldetinsae et al. 2017).

PAHs can contribute to the genotoxicity associated with petroleum refinery effluents (Wake 2005; Vargini et al. 2017). Analysis of bile fluorescence using fixed wavelength fluorescence spectrometry is a simple method that can be used to screen semi-quantitatively the recent exposure of fish to PAHs (Aas et al. 2000; Beyer et al. 2010). In the present study, a significant increase in bile fluorescence patterns corresponding to naphthalene-type, phenanthrene- type, pyrene-type, and benzo(a)pyrene-type metabolites were detected in the fish $O$. niloticus exposed to the wastewater under laboratory conditions. However, a consistent pattern was not observed either with the duration of exposure or strength of the wastewater to these PAH metabolite types. This may be associated with the differences in the absorption and metabolism of each type of PAH in the fish body as well as the degradation of PAHs in the exposed water over 


\section{N.R. Weerakkodige et al.}

time. Naphthalene-type metabolites were significantly higher in the field captured $T$. pectoralis collected from the site closest to the refinery (Site A) compared to the other sites of the Pattiwila canal. Phenanthrene-type, pyrene-type, and benzo(a)pyrene-type metabolites in $T$. pectoralis captured from other sites of the Pattiwila canal were also significantly higher than those from the reference site in most cases. Bile fluorescence patterns corresponding to naphthalene-type, phenanthrene-type, pyrene-type, and benzo(a)pyrene-type metabolites were significantly higher in the fish $D$. singhala captured from the Heiyanthuduwa canal compared to the reference site. Bile fluorescence patterns of laboratory exposed and field captured fishes indicate bioavailability of PAHs through exposure to petroleum refinery wastewater. As aromatic hydrocarbons produced by the refineries are difficult to remove from the final effluent by conventional treatment systems, a combination of additional techniques is required before it is released into the environment (Almasi et al. 2014). If the waste treatment process at the refinery is not improved, continuous genotoxic stress posed by the refinery wastewater may ultimately lead to an increase of mutations and ineffective adaption to changing environmental conditions affecting the health of native fauna especially the fish populations in the receiving waterways.

In conclusion, analysis of biomarker responses in the laboratory exposed and field captured fishes in the present study revealed that the wastewater of petroleum refinery of Sri Lanka contains genotoxic chemicals including PAHs. Hence, the release of inadequately treated refinery wastewater to the aquatic environment may pose genotoxic impacts to the biota especially the native fish populations in the receiving ecosystems. This study presents the scientific evidence for the necessity of improving current wastewater treatment technologies for reducing biological impacts. In view of human and ecosystem health under chronic exposure, genotoxicity tests may serve as powerful bioanalytical tools when regulating refinery wastewater discharges into inland waterways as they can detect potential toxicity due to interactive effects of all substances present in the wastewaters. Hence, incorporation of genotoxicity tests for final refinery wastewater quality assessments would be prudent considering sustainable development goals focusing on the ecosystem and human safety.

\section{REFERENCES}

Aas, E., J. Beyer \& A. Goksoyr. 2000. Fixed wavelength fluorescence (FF) of bile as a monitoring tool for polyaromatic hydrocarbon exposure in fish: an evaluation of compound specificity, inner filter effect and signal interpretation. Biomarkers 5: 9-23. https://doi.org/10.1080/135475000230505

Abdel-Shafy H.I. \& M.S.M. Mansour. 2016. A review on polycyclic hydrocarbons: Source, environmental impact, effect on human health and remediation. Egyptian Journal of Petroleum 25(1): 107-123.

https://doi.org/10.1016/j.ejpe.2015.03.011

Almasi, A., A. Dargahi, A. Amrane, M. Fazlzadeh, M. Mahmoudi \& A. Hashemian. 2014. Effect of the retention time and the phenol concentration on the stabilization pond efficiency in the treatment of oil refinery wastewater. Fresenius Environmental Bulletin 23(10A): 2541-2548.

Al-Sabti, K. \& C.D. Metcalfe. 1995. Fish Micronuclei for assessing genotoxicity in water. Mutation Research 343: 121-135. https://doi.org/10.1016/0165-1218(95)90078-0

Anon. 2008. The Gazette of the Democratic Socialistic Republic of Sri Lanka (Extraordinary) 1534/18: National Environmental (Protection and Quality) (Regulations), No.1 of 2008.

APHA AWWA WPCF. 1998. Standard methods for the examination of water and wastewater, 20th ed. American Publication of Health Association, Washington, DC

Arslan, Ö.Ç., M. Boyacioğlu, H. Parlak, S. Katalay \& M.A Karaaslan. 2015. Assessment of micronuclei induction in peripheral blood and gill cells of some fish species from Aliağa Bay Turkey. Marine Pollution Bulletin 94(1-2): 4854. https://doi.org/10.1016/j.marpolbul.2015.03.01 8

Baali, A., U. Kammann, R. Hanel, I.E. Qoraychy \& A. Yahyaoui. 2016. Bile Metabolites of polycyclic hysrocarbons (PAHs) in three species of fish from Morocco. Environmental Sciences Europe 28: 25. https://doi.org/10.1186/s12302-016-0093-6 
N.R. Weerakkodige et al.

Beyer, J., G. Jonsson, C. Porte, M.M. Krahn \& F. Ariese. 2010. Analytical methods for determining metabolites of polycyclic aromatic hydrocarbon $(\mathrm{PAH})$ pollutants in fish bile: A review. Environmental Toxicology and Pharmacology 30: 224-244. https://doi.org/10.1016/j.etap.2010.08.004

Botalova, O., J. Schwarzbauer, T. Frauenrath \& L. Dsikowitzky. 2009. Identification and chemical characterization of specific organic constituents of petrochemical effluents. Water Research 43: 3797-3812.

https://doi.org/10.1016/j.watres.2009.06.006

Çavaş, T. \& S. Ergene-Gözükara. 2005. Induction of micronuclei and nuclear abnormalities in Oreochromis niloticus following exposure to petroleum refinery and chromium processing plant effluents. Aquatic Toxicology 74(3): 264271.

https://doi.org/10.1016/j.aquatox.2005.06.001

Daflon, S.D.A., I.L. Guerra, M.V. Reynier, A.C. Cerqueira, C.R. Botta \& J.C. Campos. 2017. Toxicity identification and evaluation (TIE) of a petroleum refinery wastewater. Journal of Environmental Science and Health, Part A, 52: 842-848.

https://doi.org/10.1080/10934529.2017.131218 6

Gupta, A.K., I. Ahmad \& M. Ahmad. 2015. Genotoxicity of refinery waste assessed by some DNA damage tests. Ecotoxicology and Environmental Safety 114: 250-256.

https://doi.org/10.1016/j.ecoenv.2014.03.032

Hara, R.V. \& M.A. Marin-Morales. 2017. In vitro and in vivo investigation of the genotoxic potential of waters from rivers under the influence of a petroleum refinery (São Paulo State - Brazil). Chemosphere 174:321-330. https://doi.org/10.1016/j.chemosphere.2017.01 .142

Heddle, J.A., M.C. Cimino, M. Hayashi, F. Romagna, M.D. Shelby, J.D. Tucker, P. Vanparys \& J.J. MacGregor. 1991. Micronuclei as an index of cytogenic damage: past, present and future. Environmental Molecular Mutagenesis 18: 277-291.

https://doi.org/10.1002/em.2850180414

Hemachandra, C.K. \& A. Pathiratne. 2011. Analysis of bile fluorescence profiles of feral Nile tilapia as biomarkers of exposure to polycyclic aromatic hydrocarbons: associations with the rainfall. Sri Lanka Journal of Aquatic Sciences 16: 27-39.1

https://doi.org/10.4038/sljas.v16i0.6713

Hemachandra, C.K. \& A. Pathiratne. 2016. Combination of physico-chemical analysis, Allium cepa test system and Oreochromis niloticus erythrocyte based comet assay/nuclear abnormalities tests for cyto-genotoxicity assessments of treated effluents discharged from textile industries. Ecotoxicology and Environmental Safety 131: 54-64.

https://doi.org/10.1016/j.ecoenv.2016.05.010

Hemachandra, C.K. \& A. Pathiratne. 2017. Bioassessment of the effluents discharged from two export oriented industrial zones located in Kelani river basin, Sri Lanka using erythrocytic responses of the fish, Nile tilapia (Oreochromis niloticus). Bulletin of Environmental Contamination and Toxicology 99: 481-487. https://doi.org/10.1007/s00128-017-2156-9

Hintzsche, H., U. Hemmann, A. Poth, D. Utesch, J. Lott \& H. Stopper. 2017. Fate of micronuclei and micronucleated cells. Mutation Research 771: 85-98.

https://doi.org/10.1016/j.mrrev.2017.02.002

Hoshina, M.M. \& M.A. Marin-Morales. 2010. Evaluation OF the Genotoxicity of Petroleum Refinery Effluents Using the Comet Assay in Oreochromis niloticus (Nile Tilapia). Journal of the Brazilian Society of Ecotoxicology 5(1): 7579. https://doi.org/10.5132/jbse.2010.01.012

Hoshina, M.M., D. de F. Angelis \& M.A. MarinMorales. 2008. Induction of micronucleus and nuclear alterations in fish (Oreochromis niloticus) by a petroleum refinery effluent. Mutation Research/Genetic Toxicology and Environmental Mutagenesis 656(1-2): 44-48. https://doi.org/10.1016/j.mrgentox.2008.07.00 4

Iqbal, M., J. Nisar, M. Adil, M. Abbas, M. Riaz, M.A. Tahir, M. Younus \& M. Shahid. 2017. Mutagenicity and cytotoxicity evaluation of photo-catalytically treated petroleum refinery wastewater using an array of bioassays. Chemosphere 168: 590-598.

https://doi.org/10.1016/j.chemosphere.2016.11 .021

Johnson-Restrepo, B., J. Olivero-Verbel, S. Lu, J. Guette-Fernández, R. Baldiris-Avila, I. O'Byrne-Hoyos, K.M. Aldous, R. Addink \& K. Kannan. 2008. Polycyclic aromatic 
hydrocarbons and their hydroxylated metabolites in fish bile and sediments from coastal waters of Colombia. Environmental Pollution 151: 452-459. https://doi.org/10.1016/j.envpol.2007.04.011

Krahn, M.M., G.M. Ylitalo, J. Buzitis, S.L Chan, U. Varanasi, T.L Wade, T.J. Jackson, J.M. Brooks, D.A Wolfe. \& C.A. Manen. 1993. Comparison of high performance liquid chromatography/ fluorescence scanning and gas chromatography/mass spectrometry analysis for aromatic compounds in sediment samples after Exxon valdez oil spill. Environment Science and Technology 27: 699-708. https://doi.org/10.1021/es00041a013

Pathiratne, A., K.A.S. Pathiratne \& S.P.K.C. De Seram. 2010. Assessment of biological effects of pollutants in a hyper eutrophic tropical water body, Lake Beira, Sri Lanka using multiple biomarker responses of resident fish, Nile tilapia (Oreochromis niloticus). Ecotoxicology 19(6): 1019-1026. https://doi.org/10.1007/s10646-010-0483-2

Radelyuk I., K.Tussupova, J.J. Klemeš \& K.M. Persson. 2021. Oil refinery and water pollution in the context of sustainable development: Developing and development countries. Journal of Cleaner Production 302: 126987. https://doi.org/10.1016/j.jclepro.2021.126987

Ranasingha, R.A.T.C.S. \& A. Pathiratne. 2015. Histological alterations and polycyclic aromatic hydrocarbon exposure indicative bile fluorescence patterns in fishes from Koggala lagoon, Sri Lanka. Journal of National Science Foundation of Sri Lanka 43(1): 65-73. https://doi.org/10.4038/jnsfsr.v43i1.7916

Rodrigues, F.P., J.P.F. Angeli, M.S. Mantovani, C.L.B. Guedes \& B.Q. Jordão. 2010. Genetoxic evaluation of an industrial effluent from an oil refinery using plant and animal bioassays. Genetics and Molecular Biology 33(1): 169175.

https://doi.org/10.1590/S141547572010005000006

Saien, J. \& F. Shahrezaei. 2012. Organic pollutants removal from petroleum refinery wastewater with nanotitania photocatalyst and UV light emission. International Journal of Photoenergy 2012: 703074 . https://doi.org/10.1155/2012/703074

Souza, T.S. \& C.S. Fontanetti. 2006. Micronucleus test and observation of nuclear alterations in erythrocytes of Nile tilapia exposed to waters affected by refinery effluent. Mutation Research/Genetic Toxicology and Environmental Mutagenesis 605(1-2): 87-93. https://doi.org/10.1016/j.mrgentox.2006.02.01 0

Srogi, K. 2007. Monitoring of environmental exposure to polycyclic aromatic hydrocarbons: a review. Environmental Chemistry Letters 5: 169-195. https://doi.org/10.1007/s10311-0070095-0

Udroiu, I. 2006. The micronucleus test in piscine erythrocytes. Aquatic Toxicology 79: 201-204. https://doi.org/10.1016/j.aquatox.2006.06.013

Van der Oost, R., J. Beyer \& N.P.E. Vermeulan. 2003. Fish bioaccumulation and biomarkers in environmental risk assessment: a review. Environmental Toxicology and Pharmacology 13(2): 57-149. https://doi.org/10.1016/S13826689(02)00126-6

Varjani, S.J., E. Gnansounou \& A. Pandey. 2017. Comprehensive review on toxicity of persistent organic pollutants from petroleum refinery waste and their degradation by microorganisms. Chemosphere 188: 280-291.

https://doi.org/10.1016/j.chemosphere.2017.09 .005

Wake, H. 2005. Oil refineries: a review of their ecological impacts on the aquatic environment. Estuarine, Coastal and Shelf Science 62: 131140. https://doi.org/10.1016/j.ecss.2004.08.013

Weldetinsae, A., M. Dawit, A. Getahun, H.S. Patil, E. Alemayehu, M. Gizaw, M. Abate \& D. Abera. 2017. Aneugenicity and clastogenicity in freshwater fish Oreochromis niloticus exposed to incipient safe concentration of tannery effluent. Ecotoxicology and Environmental Safety 138: 98-104. https://doi.org/10.1016/j.ecoenv.2016.10.026

Wieczerzak, M., J. Namieśnik \& B. Kudłak. 2016. Bioassays as one of the Green Chemistry tools for assessing environmental quality: A review. Environment International 94: 341-361. https://doi.org/10.1016/j.envint.2016.05.017

Zar, J.H. 1998. Biostatistical Analysis. Upper Saddle River, NJ: Prentice Hall. 663p. 